\title{
Potential In Vitro Inhibition of Selected Plant Extracts against SARS-CoV-2 Chymotripsin-Like Protease (3CL ${ }^{\text {Pro }}$ ) Activity
}

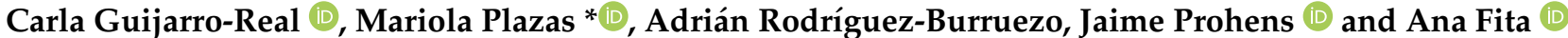

check for updates

Citation: Guijarro-Real, C.; Plazas, M.; Rodríguez-Burruezo, A.; Prohens, J.; Fita, A. Potential In Vitro Inhibition of Selected Plant Extracts against SARS-CoV-2 Chymotripsin-Like Protease (3CL ${ }^{\text {Pro }}$ ) Activity. Foods 2021, 10, 1503. https://doi.org/ $10.3390 /$ foods 10071503

Academic Editors: Filomena Nazzaro and Eng Antonio d'Acierno

Received: 17 May 2021

Accepted: 22 June 2021

Published: 29 June 2021

Publisher's Note: MDPI stays neutral with regard to jurisdictional claims in published maps and institutional affiliations.

Copyright: (c) 2021 by the authors. Licensee MDPI, Basel, Switzerland. This article is an open access article distributed under the terms and conditions of the Creative Commons Attribution (CC BY) license (https:/ / creativecommons.org/licenses/by/ $4.0 /)$.
Instituto de Conservación y Mejora de la Agrodiversidad Valenciana, Universitat Politècnica de València, 46022 Valencia, Spain; carguire@etsia.upv.es (C.G.-R.); adrodbur@upvnet.upv.es (A.R.-B.); jprohens@btc.upv.es (J.P.); anfifer@btc.upv.es (A.F.)

* Correspondence: maplaav@btc.upv.es

\begin{abstract}
Antiviral treatments inhibiting Severe acute respiratory syndrome coronavirus 2 (SARSCoV-2) replication may represent a strategy complementary to vaccination to fight the ongoing Coronavirus disease 19 (COVID-19) pandemic. Molecules or extracts inhibiting the SARS-CoV-2 chymotripsin-like protease $\left(3 \mathrm{CL}^{\text {Pro }}\right.$ ) could contribute to reducing or suppressing SARS-CoV-2 replication. Using a targeted approach, we identified 17 plant products that are included in current and traditional cuisines as promising inhibitors of SARS-CoV-2 $3 \mathrm{CL}^{\text {Pro }}$ activity. Methanolic extracts were evaluated in vitro for inhibition of SARS-CoV-2 3CL Pro activity using a quenched fluorescence resonance energy transfer (FRET) assay. Extracts from turmeric (Curcuma longa) rhizomes, mustard (Brassica nigra) seeds, and wall rocket (Diplotaxis erucoides subsp. erucoides) at $500 \mu \mathrm{g} \mathrm{mL} \mathrm{L}^{-1}$ displayed significant inhibition of the $3 \mathrm{CL}^{\text {Pro }}$ activity, resulting in residual protease activities of $0.0 \%$, $9.4 \%$, and $14.9 \%$, respectively. Using different extract concentrations, an $\mathrm{IC}_{50}$ value of $15.74 \mu \mathrm{g} \mathrm{mL}$ was calculated for turmeric extract. Commercial curcumin inhibited the $3 \mathrm{CL}^{\text {Pro }}$ activity, but did not fully account for the inhibitory effect of turmeric rhizomes extracts, suggesting that other components of the turmeric extract must also play a main role in inhibiting the $3 \mathrm{CL}^{\text {Pro }}$ activity. Sinigrin, a major glucosinolate present in mustard seeds and wall rocket, did not have relevant $3 \mathrm{CL}^{\text {Pro }}$ inhibitory activity; however, its hydrolysis product allyl isothiocyanate had an $\mathrm{IC}_{50}$ value of $41.43 \mu \mathrm{g} \mathrm{mL} \mathrm{mL}^{-1}$. The current study identifies plant extracts and molecules that can be of interest in the search for treatments against COVID-19, acting as a basis for future chemical, in vivo, and clinical trials.
\end{abstract}

Keywords: allyl isothiocyanate; COVID-19; curcumin; FRET assay; mustard seeds; natural com-

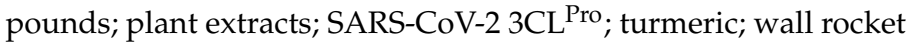

\section{Introduction}

Severe acute respiratory syndrome coronavirus 2 (SARS-CoV-2) is a predominantly airborne transmitted coronavirus first identified in December 2019, which is the causal agent of Coronavirus disease 19 (COVID-19) [1]. Rapid spread of SARS-CoV-2 has caused a severe pandemic, resulting so far in a death toll of almost 3 million lives worldwide [2] and a disruption of many aspects of human daily life. SARS-CoV-2 is an enveloped, simple-stranded, positive-sense RNA virus with a length of $29.9 \mathrm{~kb}$ and a diameter of about 65-125 nm [3]. Since its identification, the genome of multiple strains of SARS-CoV-2 has been sequenced [4-6] and its life cycle has been thoroughly studied [3].

Many vaccine projects have been developed and are underway to fight COVID-19 [7]. Several of the first-generation vaccines already in use in vaccination campaigns have shown high levels of efficacy, albeit the level of protection is not complete and seems to be strain-dependent. In this way, the recent appearance of new highly infectious SARS-CoV-2 strains might reduce the efficacy of first-generation vaccines [8]. Moreover, vaccines are still in short supply and, in many countries, vaccination against SARS-CoV-2 is neither compulsory nor indicated for some specific groups, such as children, or people with certain 
medical conditions $[9,10]$. Therefore, the development of therapies complementary to vaccination is desirable for a comprehensive fight against COVID-19.

The development of drugs for the treatment of COVID-19 patients so far has not resulted in highly efficient or curative drug therapies. Despite the initial consideration of some pre-existent drugs as potential antiviral against SARS-CoV-2, no proven effective treatments have been found so far [11]. Among the proteins encoded by the SARS-CoV-2 RNA, the chymotrypsin-like protease $\left(3 \mathrm{CL}^{\mathrm{Pro}}\right)$, also known as main protease $\left(\mathrm{M}^{\mathrm{Pro}}\right)$, is required for the proteolytic processing of the viral polyproteins during the maturation step, thus becoming an essential tool for the successful replication of the virus [12]. In this sense, the fundamental role of the $3 \mathrm{CL}^{\mathrm{Pro}}$ in viral replication makes this enzyme an attractive target for the development of drugs inhibiting the virus replication. A similar research strategy was followed in the past against the phylogenetically related SARS-CoV [13], which caused the SARS-CoV 2002-2004 outbreak, and led to the screening of a large variety of molecules and natural products for their inhibition of the SARS-CoV 3CL ${ }^{\text {Pro }}$ activity [14]. In addition to single molecules, some plant extracts also inhibited the SARS-CoV $3 \mathrm{CL}^{\text {Pro }}$ activity in vitro $[15,16]$.

Some natural compounds with potential against SARS-CoV-2 have been identified based on the work with SARS-CoV and related viruses and through in silico molecular docking studies [17-21]. The recent work of Zhou and Huang [22] reviews the current findings regarding natural compounds that might be considered for their potential antiviral activity against SARS-CoV-2, mostly based on previous experience with other coronaviruses. Some compounds found in edible and/or medicinal plant products were identified in these studies as potential natural compounds targeting the SARS-CoV-2 $3 \mathrm{CL}^{\text {Pro }}$, including glucosinolates, flavonoids, and other phenolic compounds. Phenolic compounds have been extensively studied for their antioxidant capacity acting as free radical scavengers tested in vitro and using in vivo models [23]. Thus, diets rich in fruits and vegetables containing high levels of these compounds are associated with a reduction in the risk of chronic inflammatory processes, thus lowering the risk of developing some degenerative and cardiovascular diseases and several types of cancer, and increasing the overall health status [24-26]. In addition, glucosinolates and their hydrolytic products are also bioactive molecules related to the maintenance of a good health status. The most studied derivative, sulforaphane, proved to induce detoxification phase II enzymes [27] and has been studied as an anticarcinogen likely able to be effective in all stages of cancer [28], to reduce the risk of developing type 2 diabetes [29], as well as to ameliorate several neurodegenerative diseases [30]. Other glucosinolates are promising as natural compounds by exerting antimicrobial activities [31,32].

However, the evaluation of the antiviral capacity of these groups of natural compounds is more limited. Based on this consideration, the current work aimed at the targeted testing for inhibitory capacity against the $3 \mathrm{CL}^{\text {Pro }}$ activity of plant extracts selected for being rich in one or more of the aforementioned chemical families. The materials selected constitute common food products in many cultures and are of easy access or, alternatively, grow profusely in many regions and are included in traditional cuisines, as is the case of wall rocket in the Mediterranean region. A cell-free cleavage assay using a fluorogenic substrate was used, as this technique has been used successfully to measure the protease activity of the related SARS-CoV $3 \mathrm{CL}^{\text {Pro }}$ [33-35]. Testing plant extracts can be considered a first approach in the search for natural compounds with antiviral activity, or even represent a basis for the development of prophylactic or therapeutic plant extracts against COVID-19. In addition, given the proven safety for human consumption of the plants from which extracts are obtained, their potential use against COVID-19 might be immediate and easily accessible. 


\section{Materials and Methods}

\subsection{Plant Material}

A total of 17 plant foods and derived products were selected for the current study (Figure S1). The materials were identified by the authors and acquired in a local market at Valencia (Spain) and included citrus fruit peels (sweet orange (Citrus sinensis), lemon (C. limon), lime (C. aurantiifolia), and grapefruit (Citrus paradisi)), seasoning and aromatic herbs (celery leaves and celery stalks (Apium graveolens var. dulce), parsley (Petroselinum crispum), dill (Anethum graveolens), sweet chamomile (Marticaria chamomilla), and dried oregano (Origanum vulgare)), bulbs and rhizomes (red onion (Allium cepa) and turmeric (Curcuma longa)), a succulent plant (aloe vera (Aloe barbadensis)), and cruciferous condiments (brown mustard seeds (Brassica nigra), horseradish (Armoracia rusticana), and commercial wasabi powder (Tokyo-Ya, S.A., Japan)). The ingredients of wasabi powder were horseradish, mustard, vitamin C, acidulant E334, wasabi aroma, and colorants E102 and E133. Dried oregano and sweet chamomile were acquired from Naturcid S.L. (Monforte del Cid, Spain), and mustard seeds were acquired from Diplan S.A. (Fuenlabrada, Spain). In addition, edible baby-leaves of wall rocket or wild rucola (Diplotaxis erucoides subsp. erucoides) were included in the study owing to their accumulation of sinigrin, which derives in allyl isothiocyanate $[36,37]$. Wall rocket is an herbaceous plant broadly distributed and included in the traditional Mediterranean cuisine and, for the current study, it was grown in the field as described in Guijarro-Real et al. [36]. The selection of these plant materials (Table 1) was done according to their phytochemical composition as reported in the literature, based on the recent review work by Zhou and Huang [22].

Approximately, $100 \mathrm{~g}$ to $200 \mathrm{~g}$ of material was obtained for each sample. For citrus fruits, the peels (including the flavedo and albedo) were manually separated from the flesh and used because of the higher concentrations of flavonoids in the former [38]. Celery was separated into leaves and stalks and processed separately. Turmeric and horseradish were peeled, and peels were discarded. Aloe vera leaves were separated into the outer skin and the inner parenchyma, and the former was discarded. Except for dried oregano, all materials were freeze-dried. Dried materials were ground into powder with a coffee grinder and stored at $-80^{\circ} \mathrm{C}$.

Table 1. Selected phytochemical compounds reported as potential natural inhibitors of SARS-CoV-2 $3 \mathrm{CL}^{\text {Pro }}$ activity and naturally present in the plant materials used in the current study.

\begin{tabular}{|c|c|c|c|}
\hline Compound & Chemical Family & Plant Material & References \\
\hline \multirow{4}{*}{ Hesperetin } & \multirow{4}{*}{ Flavonoids } & Grapefruit & [39-42] \\
\hline & & Lemon & {$[43,44]$} \\
\hline & & Lime & {$[45,46]$} \\
\hline & & Orange & {$[39,40]$} \\
\hline \multirow{2}{*}{ Luteolin } & \multirow{2}{*}{ Flavonoids } & Celery & [47-49] \\
\hline & & Oregano & {$[50,51]$} \\
\hline \multirow{3}{*}{ Quercetin } & \multirow{3}{*}{ Flavonoids } & Dill & [52] \\
\hline & & Red onion & {$[48,49]$} \\
\hline & & Celery & {$[47,48]$} \\
\hline \multirow{3}{*}{ Apigenin } & \multirow{3}{*}{ Flavonoids } & Chamomile & {$[53,54]$} \\
\hline & & Oregano & {$[50,51]$} \\
\hline & & Parsley & {$[47,52]$} \\
\hline \multirow{2}{*}{ Curcumin } & \multirow{2}{*}{ Curcuminoids } & Turmeric & {$[55,56]$} \\
\hline & & Mustard & {$[57,58]$} \\
\hline \multirow{3}{*}{ Sinigrin } & \multirow{3}{*}{ Glucosinolates } & Horseradish & {$[59,60]$} \\
\hline & & Wasabi condiment ${ }^{1}$ & [37] \\
\hline & & Wall rocket & {$[36,61]$} \\
\hline Aloe emodin & Anthraquinones & Aloe vera & [62] \\
\hline
\end{tabular}

\footnotetext{
${ }^{1}$ The wasabi was obtained as commercial wasabi powder; for ingredients, refer to Section 2.1.
} 


\subsection{Preparation of Methanolic Extracts}

Phytochemical compounds were extracted from samples with $80 \%$ aqueous methanol, which has been proven as an appropriate solvent for the extraction of phenolic compounds [63,64] and glucosinolates [65]. For each material, four samples of $100 \mathrm{mg}$ were extracted with $1 \mathrm{~mL}$ of $80 \%$ methanol upon sonication for $30 \mathrm{~min}$, with intermediate stirring each $5 \mathrm{~min}$ to facilitate the extraction process. After a centrifugation step ( $5 \mathrm{~min}$ at $13,000 \mathrm{rpm}$ ), the plant material was re-extracted by adding $1 \mathrm{~mL}$ of $80 \%$ methanol. The recovered extracts of four independent replicates were combined and filtered through a $0.2 \mu \mathrm{m}$ PTFE filter. Then, $5 \mathrm{~mL}$ of the combined extract for each material was dried under nitrogen and resuspended for a stock solution in 100\% dimethyl sulfoxide (DMSO) to a final concentration of $50 \mathrm{mg} \mathrm{mL}{ }^{-1}$. Extracts were kept at $-80^{\circ} \mathrm{C}$ until analysis.

\subsection{FRET Assay for the Inhibition of the 3CL Protease Activity (SARS-CoV-2 3CL Pro)}

The extracts were evaluated as inhibitors of SARS-CoV-2 3CL Pro by means of an in vitro quenched fluorescence resonance energy transfer (FRET) assay using a fluorogenic substrate to measure the residual activity. For the study, the MBP-tagged 3CL Protease (SARS-CoV-2) Assay Kit (BPS Bioscience, San Diego, CA, USA) was used according to the manufacturer's instructions. Briefly, the plant-based extracts were conveniently diluted in the $3 \mathrm{CL}^{\text {Pro }}$ assay buffer to an extract concentration of $2.5 \mathrm{mg} \mathrm{mL}^{-1}$. For determination of the $3 \mathrm{CL}^{\text {Pro }}$ activity, $5 \mu \mathrm{L}$ of the diluted plant extracts was pre-incubated with $150 \mathrm{ng}$ of the $3 \mathrm{CL}^{\text {Pro }}$ for $30 \mathrm{~min}$. Subsequently, the fluorogenic substrate was added to a final concentration of $50 \mu \mathrm{M}$ and the reaction was incubated for $4 \mathrm{~h}$ in the darkness in the presence of $1 \mathrm{mM}$ 1,4-dithio-D,L-threitol (DTT). The final concentration of the plant extracts during the reaction was $500 \mu \mathrm{g} \mathrm{mL}^{-1}$ in a reaction volume of $25 \mu \mathrm{L}$. The fluorescence intensity was recorded at $470 \mathrm{~nm}$ after excitation at $360 \mathrm{~nm}$. A positive control was included to measure the maximum activity of the protease in the absence of potential inhibitors. Moreover, an inhibition control was included by pre-incubating $150 \mathrm{ng}$ of the $3 \mathrm{CL}^{\text {Pro }}$ with $5 \mu \mathrm{L}$ of the inhibitor GC376 $(250 \mu \mathrm{M})$ supplied by the manufacturer. The reaction was evaluated in four replicates for each extract.

The extracts showing significant inhibition of the $3 \mathrm{CL}^{\text {Pro }}$ activity $(<20 \%$ of residual activity compared with the positive control) were selected for the determination of the correspondent $\mathrm{IC}_{50}$. The protocol followed was the same as described above, although in this case, seven concentrations of the plant-based extracts, 5.0-10-25-50-100-200-500 $\mathrm{gg} \mathrm{mL}^{-1}$, were evaluated. Additionally, commercial standards of curcumin ( $>94 \%$ curcuminoids with $>80 \%$ curcumin, CAS Number 458-37-7), sinigrin (CAS Number 3952-98-5), and allyl isothiocyanate (CAS Number 57-06-7) (Sigma-Aldrich, Saint Louis, MO, USA) were also resuspended in DMSO and tested as $3 \mathrm{CL}^{\text {Pro }}$ activity inhibitors at different concentrations. As for the first screening, the inhibitory capacity of the plant extracts and the commercial standards was tested using four replicates for each concentration considered.

\subsection{Data Analysis}

The fluorescence intensity measured indicated the residual activity of the protease after the co-incubation with extracts. The residual activities were provided in percentage against the maximum activity obtained in the absence of potential inhibitory compounds or extracts $(100 \%)$. For each material and concentration tested, the average value and corresponding standard error were calculated $(n=4)$ using the statistics software Statgraphics Centurion XVII (Statpoint Technologies, Warrenton, VA, USA), and the significance of differences among materials was tested by one-way factorial analysis of variance. Mean separation was performed with a Student-Newman-Keuls test at a signification level of $p<0.05$. The dose-response curves and the relative $\mathrm{IC}_{50}$ for extracts and standards showing significant inhibition were obtained using the GraphPad Prism 9.0.1 software (GraphPad Software, San Diego, CA, USA). 


\section{Results}

\subsection{Screening of Plant-Based Extracts for Inhibition of SARS-CoV-2 3CL Pro Activity}

The inhibition of SARS-CoV-2 3CL Pro activity by the 17 extracts was tested at a final concentration of $500 \mu \mathrm{g} \mathrm{mL}{ }^{-1}$. The extracts of lime peel and chamomile produced signal interferences and were discarded from the analysis. It was noted, however, that the coincubation of the $3 \mathrm{CL}^{\text {Pro }}$ with the chamomile extracts produced a reduction of the protease activity even if a signal interference was observed (Figure S2).

The results of the inhibitory activity of SARS-CoV-2 3CL Pro of the remaining 15 extracts tested at a concentration of $500 \mu \mathrm{g} \mathrm{mL}^{-1}$ are displayed in Figure 1. Seven of the materials showed low inhibitory capacity and led to average residual protease activities over $70 \%$. This group included extracts of grapefruit, lemon, and orange fruit peels $(72.4-82.8 \%$ of mean residual activities); red onion (80.9\%); celery stalk $(79.9 \%)$; horseradish $(75.0 \%)$; and dill (73.1\%). Five other materials displayed intermediate inhibitory capacity (35-55\%), including extracts of celery leaves $(38.0 \%)$, parsley $(42.8 \%)$, and oregano $(46.3 \%)$ herbs; aloe vera leaves (54.8\%); and the wasabi powder (35.8\%). Finally, three extracts were found to show high inhibitory capacity and included mustard seeds (9.4\%), wall rocket (14.9\%), and turmeric, the latter showing a complete inhibitory capacity $\left(0.0 \%\right.$ of $3 \mathrm{CL}^{\text {Pro }}$ residual activity) at the concentration of $500 \mu \mathrm{g} \mathrm{mL}{ }^{-1}$.

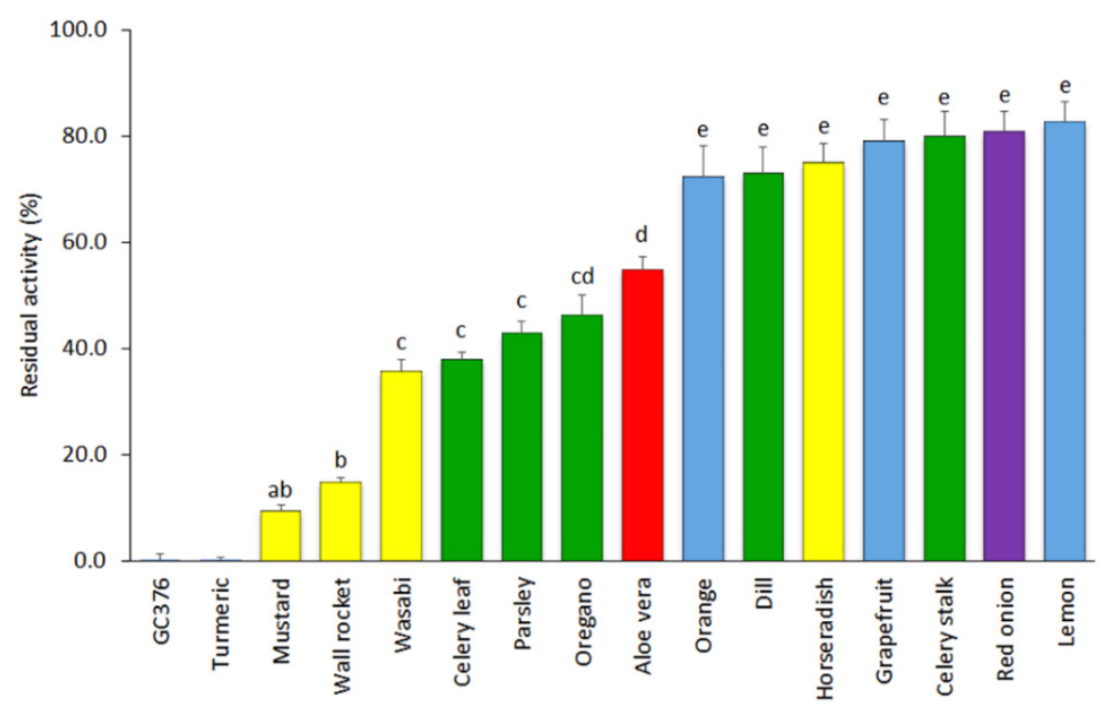

Figure 1. Mean values and standard errors (SEs) for the residual activity of SARS-CoV-2 3CL Pro in the presence of the fifteen plant-based extracts at a concentration of $500 \mu \mathrm{g} \mathrm{mL} \mathrm{m}^{-1}$ and the inhibitor control GC376 at a concentration of $50 \mu \mathrm{M}(n=4)$. Extracts included were obtained from citrus fruit peels (blue), seasoning and aromatic herbs (green), bulbs and rhizomes (purple; includes turmeric), a succulent plant (red), and cruciferous herbs and condiments (yellow). Both the turmeric extract and the inhibitor GC376 produced a complete inhibition of the $3 \mathrm{CL}^{\text {Pro }}$. Different letters indicate significant differences in the $3 \mathrm{CL}^{\text {Pro }}$ residual activity according to a Student-Newman-Keuls test at $p<0.05$.

\subsection{Determination of the $I C_{50}$ Values of Extracts with High SARS-CoV-2 3CL Pro Activity Inhibition}

According to the initial screening at $500 \mu \mathrm{g} \mathrm{mL}^{-1}$, the mustard seeds, wall rocket leaves, and turmeric powder extracts were selected owing to their high SARS-CoV-2 3CL Pro activity inhibitory potential. For these materials, the dose-dependent inhibitory curves were obtained and the corresponding $\mathrm{IC}_{50}$ values were calculated by testing the plant extracts at eight final concentrations ranging between 5.0 and $500 \mu \mathrm{g} \mathrm{mL}^{-1}$.

The dose-dependent inhibition curve for the turmeric powder was obtained by testing the residual activity of the SARS-CoV-2 $3 \mathrm{CL}^{\text {Pro }}$ after the co-incubation with the plant extracts at the final concentrations of 5.0-10-25-50-100-200-500 $\mathrm{g} \mathrm{mL}^{-1}$. The logarithmic dose-response curve was fitted to a sigmoidal curve with an $r^{2}$ value of 0.976 and an $\mathrm{IC}_{50}$ 
for turmeric of $15.74 \mu \mathrm{g} \mathrm{mL}^{-1}$ was determined. The highest concentrations tested, i.e., from $100 \mu \mathrm{g} \mathrm{mL}^{-1}$ (log [turmeric] = 2.0) to $500 \mu \mathrm{g} \mathrm{mL}^{-1}$ (log [turmeric] = 2.7), resulted in a very high inhibition of the SARS-CoV-2 3CL Pro activity (Figure 2). In order to test whether the curcumin present in the turmeric material accounted for such inhibition, an additional analysis using commercial curcumin ( $>94 \%$ curcuminoids, $>80 \%$ curcumin) was conducted at concentrations of $2.5-75 \mu \mathrm{g} \mathrm{mL}^{-1}$ (log [curcumin] $\left.=0.4-1.9\right)$. Higher concentrations of the compound could not be tested because of its insolubility in the reaction buffer. As expected, the co-incubation of $3 \mathrm{CL}^{\text {Pro }}$ with curcumin also showed a positive effect on the protease inhibition. Thus, concentrations over $30 \mu \mathrm{g} \mathrm{mL}^{-1}$ (log [curcumin] $=1.5$ ) produced a residual protease activity below $50 \%$, which decreased to $28.1 \%$ when the compound was tested at $75 \mu \mathrm{gL} \mathrm{m}^{-1}(\log$ [curcumin] $=1.9)$ (Figure 2).

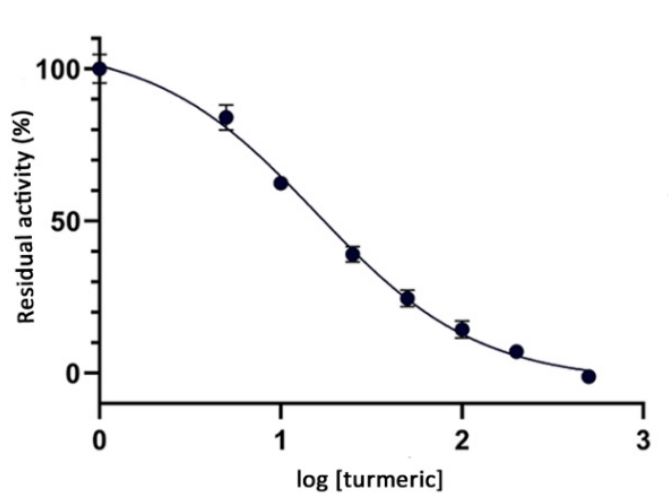

(a)

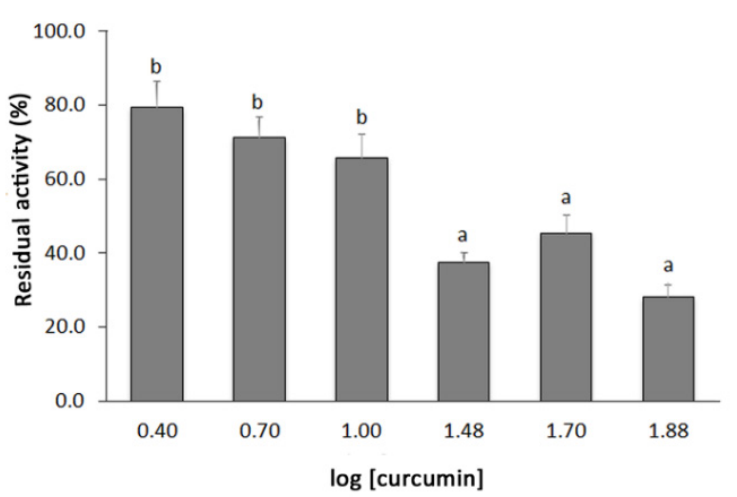

(b)

Figure 2. (a) Dose-response curve for the methanolic extract of turmeric powder. Each point represents the average value and SE for the residual activity of the $3 \mathrm{CL}^{\text {Pro }}(\%)$ at extract concentrations between 5.0 and $500 \mu \mathrm{g} \mathrm{mL}-1(n=4)$. The $100 \%$ of residual activity considers the activity of the $3 \mathrm{CL}^{\text {Pro }}$ when no inhibitor is added. (b) Mean residual activity and SE of $3 \mathrm{CL}^{\text {Pro }}(\%)$ determined after the co-incubation with five different concentrations of commercial curcumin $(2.5-75 \mu \mathrm{g} \mathrm{mL}-1)(n=4)$. Different letters indicate significant differences in the $3 \mathrm{CL}^{\text {Pro }}$ residual activity according to a Student-Newman-Keuls test at $p<0.05$.

The extracts of mustard seeds showed strong inhibitory capacity at the highest doses tested. Thus, the co-incubation with $200 \mu \mathrm{g} \mathrm{mL}^{-1}$ (log (mustard) $=2.3$ ) and $500 \mu \mathrm{g} \mathrm{mL}$ $(\log ($ mustard $)=2.7)$ of the extract reduced the activity of SARS-CoV-2 $3 \mathrm{CL}^{\text {Pro }}$ to $42.1 \%$ and $9.4 \%$, respectively (Figure 3 ). By contrast, the co-incubation with $100 \mu \mathrm{g} \mathrm{mL} \mathrm{m}^{-1}$ (log (mustard) $=2.0$ ) of mustard seeds extract only inhibited such activity by $19.9 \%$ (residual activity $=80.1 \%)$. The $\mathrm{IC}_{50}$ for the mustard seeds extract was $128.1 \mu \mathrm{g} \mathrm{mL}^{-1}\left(r^{2}\right.$ value 0.865$)$ (Figure 3). In the case of wall rocket extracts, the co-incubation produced residual activities of the $3 \mathrm{CL}^{\text {Pro }}$ ranging between $94.3 \%$ and $15.8 \%$ for $5.0 \mu \mathrm{g} \mathrm{mL}{ }^{-1}$ (log (wall rocket) $=0.7$ ) and $500 \mu \mathrm{g} \mathrm{mL}^{-1}(\log$ (wall rocket) $=2.7$ ) of extract, respectively. The co-incubation with $200 \mu \mathrm{g} \mathrm{mL} \mathrm{m}^{-1}$ of extract produced an inhibitory response of $56.8 \%$ compared with the absence of extract. For this material, the $\mathrm{IC}_{50}$ estimated from the dose-response curve was $257.4 \mu \mathrm{g} \mathrm{mL}^{-1}\left(r^{2}\right.$ value 0.937 ) (Figure 3).

Given that both mustard and wall rocket were selected for containing glucosinolates, particularly sinigrin, both sinigrin and its hydrolytic derivative were evaluated for their SARS-CoV-2 3CL Pro inhibition activity. Allyl isothiocyanate is naturally released in plants from its precursor owing to the activity of the endogenous plant myrosinases [66]. The coincubation of the $3 \mathrm{CL}^{\text {Pro }}$ with the purified sinigrin did not result in a significant reduction of the protease activity even at the highest concentration tested, $500 \mu \mathrm{g} \mathrm{mL}^{-1}$. By contrast, the co-incubation with allyl isothiocyanate at $500 \mu \mathrm{g} \mathrm{mL}-1(\log ($ allyl isothiocyanate $)=2.7)$ resulted in a complete inhibition of the $3 \mathrm{CL}^{\text {Pro }}$ activity. Therefore, the dose-response curve was obtained for allyl isothiocyanate. The response fitted to a sigmoidal curve $\left(r^{2}\right.$ value 0.943 ) with an estimated $\mathrm{IC}_{50}$ of $41.43 \mu \mathrm{g} \mathrm{mL} \mathrm{m}^{-1}$ allyl isothiocyanate standard (Figure 3). 


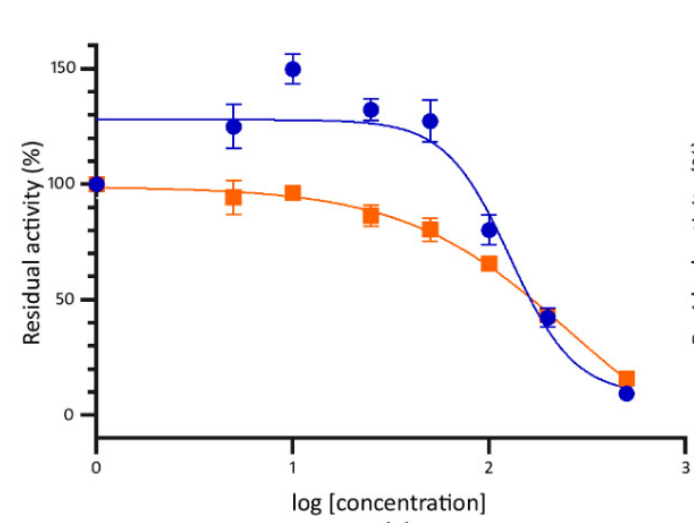

(a)

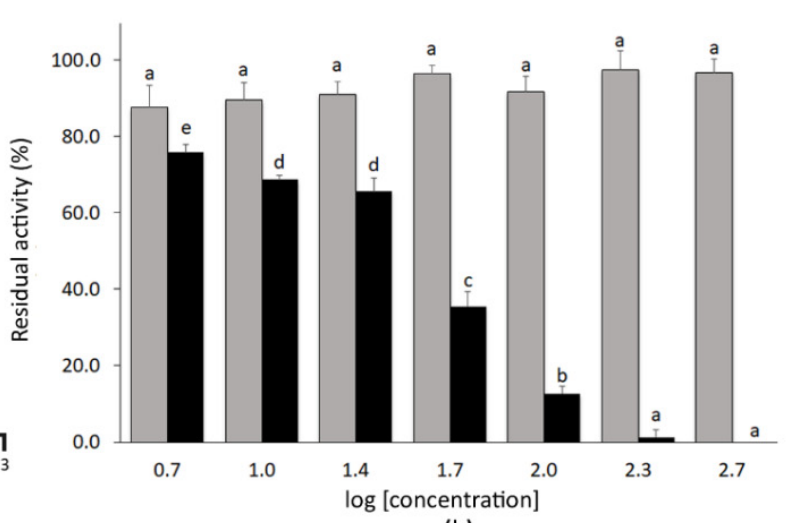

(b)

Figure 3. (a) Dose-response curve for the methanolic extracts of mustard seeds (blue circles) and wall rocket leaves (orange squares). Each point represents the average value and SE for the residual activity of the $3 \mathrm{CL}^{\text {Pro }}(\%)$ at extract concentrations between 5.0 and $500 \mu \mathrm{g} \mathrm{mL}^{-1}(n=4)$. The $100 \%$ of residual activity is the activity of the $3 \mathrm{CL}^{\text {Pro }}$ when no inhibitor is added. (b) Mean residual activity and SE of $3 \mathrm{CL}^{\text {Pro }}$ (\%) determined after the co-incubation with $5.0-500 \mu \mathrm{g} \mathrm{mL} \mathrm{m}^{-1}$ of sinigrin (grey) and allyl isothiocyanate (black) standards $(n=4)$. Different letters indicate significant differences in the 3CLPro residual activity for sinigrin or allyl isothiocyanate treatments according to two separate Student-Newman-Keuls tests at $p<0.05$.

\section{Discussion}

The recent COVID-19 disease pandemic caused by the SARS-CoV-2 coronavirus has resulted in a global health crisis. Although other coronaviruses were responsible for previous outbreaks in the last two decades [67], the fast spread of SARS-CoV-2 has demonstrated the threat to human health of new coronaviruses. One year after the disease was declared as a pandemic [68], COVID-19 is still causing thousands of daily deaths and no effective treatments apart from preventive vaccination are reported for fighting the infection process. Obtaining effective treatments against SARS-CoV-2 is urgently needed because, in combination with vaccines, they may become a first line therapy not only for current SARS-CoV-2 strains, but also for new ones.

The $3 \mathrm{CL}^{\text {Pro }}$ is considered as one of the most promising targets for the development of antiviral drugs against coronaviruses [69]. The three-dimensional structure of SARSCoV-2 3CL Pro was unraveled by Zhang et al. [12]. The enzyme has an identity percentage of $96 \%$ with SARS-CoV 3CL Pro, thus it has been inferred that both proteases have very similar specificities [70,71]. These works suggest that molecules and extracts that displayed inhibitory activity against SARS-CoV $3 \mathrm{CL}^{\text {Pro }}$ might be also of interest to inhibit the activity of SARS-CoV-2 3CL ${ }^{\text {Pro }}$. In this context, our work used a targeted approach based on previous information on inhibitors SARS-CoV 3CL Pro [22]. For the current study, plantbased extracts potentially promising for the inhibition of SARS-CoV-2 3CL Pro activity were tested. Previous studies with plant-based extracts have been conducted in the past to test their inhibitory capacity against SARS-CoV 3CL Pro, with promising results [15,16,72].

The first screening with plant extracts at $500 \mu \mathrm{g} \mathrm{mL}{ }^{-1}$ revealed that the extracts of the three citrus fruits peels produced a low reduction of the protease activity. Flavonoids present in citrus fruits have been suggested as potential antivirals against coronaviruses and in therapeutics fighting the inflammation process that can derive in more severe symptoms of the viral disease $[73,74]$. Recent works based on computational molecular docking pointed to the flavanone hesperidin, which is the glycosylated form of hesperetin and the main form in which this flavonoid is found in citrus fruits, as one natural compound displaying high capacity for binding to the SARS-CoV-2 3CL Pro [71,75]. However, our results showed that citrus fruit peels, which contain high concentrations of hesperidin [44], had a low in vitro inhibitory activity against SARS-CoV-2 3CL ${ }^{\text {Pro }}$.

Interestingly, extracts of turmeric powder, mustard seeds, and wall rocket leaves produced the highest reduction in SARS-CoV-2 3CL Pro activity. Turmeric rhizomes are rich in the flavonoid curcumin and its derivatives, natural compounds that have been also 
considered in molecular docking studies for their potential inhibitory capacity against SARS-CoV-2 3CL ${ }^{\text {Pro }}$ [75-77]. According to these studies, curcumin and its derivatives can be considered as natural compounds with potential as $3 \mathrm{CL}^{\text {Pro }}$ inhibitors, although the same works showed that other flavonoids might have higher potential inhibitory activity according to the docking results. In concordance, our FRET assay revealed a high inhibitory capacity of the turmeric rhizomes extracts against the $3 \mathrm{CL}^{\text {Pro }}$ activity. The turmeric extracts were, in fact, the most effective among all the plant-based extracts evaluated in the inhibitory activity. In this respect, other plant-based extracts were evaluated in the past against SARS-CoV 3CL Pro activity and showed lower inhibitory capacity. Ryu et al. [72] found that ethanolic extracts of Torreya nucifera tested at $100 \mu \mathrm{g} \mathrm{mL}^{-1}$ resulted in $62 \%$ of activity inhibition against SARS-CoV $3 \mathrm{CL}^{\text {Pro }}$, while in our case, the same concentration of turmeric extract resulted in a reduction of $86 \%$ for SARS-CoV-2 $3 \mathrm{CL}^{\text {Pro }}$ activity. In another study, an $\mathrm{IC}_{50}$ was determined for SARS-CoV $3 \mathrm{CL}^{\text {Pro }}$ activity that ranged between 25 and $70 \mu \mathrm{g} \mathrm{mL}^{-1}$ for black and Puer tea extracts [15], while for the turmeric extracts, we found an $\mathrm{IC}_{50}$ of 1.6- to 4.5 -fold lower than these against SARS-CoV-2 3CL ${ }^{\text {Pro }}$.

The concentration of curcumin in turmeric powder is generally around $3 \%$ or lower [78], while the concentration of other curcuminoids is even lower [79]. However, commercial curcumin ( $>80 \%$ curcumin) even at concentrations of $75 \mu \mathrm{g} \mathrm{mL} L^{-1}$, which is several-fold the expected concentration of curcumin in the turmeric extract at $500 \mu \mathrm{g} \mathrm{mL} \mathrm{L}^{-1}$, did not cause a complete inhibition of SARS-CoV-2 3CL Pro activity. This result suggests that other components of turmeric or their synergetic interaction may have a major contribution to the inhibition of SARS-CoV-2 3CL Pro activity. In this sense, turmeric rhizomes also contain the curcuminoid demethoxycurcumin [56], which has also been described as a potential inhibitor against SARS-CoV-2 $3 \mathrm{CL}^{\text {Pro }}$, even showing greater affinity than curcumin for SARS-CoV-2 3CL ${ }^{\text {Pro }}$ in the docking analysis of Khaerunnisa et al. [77]. Furthermore, turmeric powder also contains sesquiterpenoids [79] and quercetin derivatives [80], the latter also being considered as a potential inhibitor of SARS-CoV-2 3CL ${ }^{\text {Pro }}[77,81]$. Thus, the inhibitor capacity of turmeric extracts might be the result of a synergistic activity of several compounds. Overall, our results indicate that extracts of turmeric are a strong candidate for being tested for inhibiting the in vivo replication of SARS-CoV-2. Moreover, considering these results, further studies should be addressed to characterize the methanolic extracts of turmeric powder and to individually test the compounds present.

On the other hand, two cruciferous extracts (from mustard seeds and wall rocket) that are rich in sinigrin $[36,57,58,61]$ were found to exert a strong inhibition of SARS-CoV-2 $3 \mathrm{CL}^{\text {Pro }}$ activity. Sinigrin is the precursor glucosinolate of allyl isothiocyanate, a reactive molecule displaying antimicrobial $[82,83]$ and anticarcinogenic properties [84-86]. By contrast, references to the potential of either sinigrin or allyl isothiocyanate as antivirals are more limited [16]. These latter authors found that sinigrin had good potential as an inhibitor against SARS-CoV $3 \mathrm{CL}^{\text {Pro }}$. In our case, we found that sinigrin has a low effect as in vitro inhibitor of SARS-CoV-2 3CL Pro, while its derivative allyl isothiocyanate is a powerful inhibitor of SARS-CoV-2 3CL ${ }^{\text {Pro }}$ activity. In this way, isothiocyanate metabolites might be responsible, at least in part, for the antiviral properties of these cruciferous plants extracts, which is probably related to their chemical structure, i.e., organosulfur molecules acting as H2S donors [87]. In fact, Blanchard et al. [14] previously reported a good response of sulfur-containing compounds against SARS-CoV $3 \mathrm{CL}^{\text {Pro }}$ activity owing to their capacity of forming covalent adducts between their electrophilic group and a nucleophile side chain of the protease. Therefore, our results suggest that the sinigrin derivative allyl isothiocyanate is a good candidate molecule for being tested in vivo for inhibiting SARS-CoV-2 $3 \mathrm{CL}^{\text {Pro }}$ activity. However, the high cytotoxicity of allyl isothiocyanate may preclude its practical use [83], which would depend on the concentration required. In this sense, further analysis of the methanolic extracts for mustard and wall rocket would increase the knowledge regarding the concentration at which these compounds are found, and the possible presence of other metabolites also exerting potential inhibitory activities. 
This work is a first targeted approach for the evaluation of plant extracts and containing natural compounds for the development of prophylaxis, adjuvant therapies, and drug treatments aimed at inhibiting the activity of SARS-CoV-2 $3 \mathrm{CL}^{\text {Pro }}$. Extracts of turmeric have been identified as a candidate plant extract for reducing SARS-CoV-2 3CL Pro activity, which could eventually affect the viral replication. In addition, other plant extracts, such as those of cruciferous plants containing sinigrin, which, after consumption, is degraded to allyl isothiocyanate, might be considered as well for their inhibition of SARS-CoV-2 3CL Pro activity. The current study provides information that can help in the search for treatments against COVID-19, acting as a basis for future chemical, in vivo, and clinical trials. Thus, further studies following the results of this work should be addressed: (1) to chemically characterize the plant extracts with high potential inhibitory activity and to re-evaluate this capacity after the fractionation of the extracts, thus allowing the identification of the biomolecules responsible of such activity and possible synergistic effects; and (2) to evaluate this potential inhibition in cell-based studies where the virus, host cell, and plant extract interact, also determining the toxicity limit prior to conducting other pre-clinical and clinical trials.

Supplementary Materials: The following are available online at https:/ /www.mdpi.com/article/ 10.3390/foods10071503/s1, Figure S1: Materials used for the analysis, from left to right and top to bottom: orange peel, lemon peel, lime peel, grapefruit peel, celery leaves, celery stalk, parsley leaves, dill leaves, dried oregano leaves, red onion bulb, turmeric rhizomes, aloe leaf, chamomile, mustard seeds, horseradish root, wasabi powder, and wall rocket leaves; Figure S2: Signal recorded at wavelengths between 400 and $550 \mathrm{~nm}$ for the residual activity of the $3 \mathrm{CL}^{\mathrm{Pro}}$ without inhibition (Control), after co-incubation with chamomile extracts at concentrations of $200 \mu \mathrm{g} \mathrm{mL}{ }^{-1}$ or $500 \mu \mathrm{g} \mathrm{mL}^{-1}$, after co-incubation with the inhibitor GC376 at $50 \mu \mathrm{M}$ (GC376), and the signal of the raw chamomile extract at a concentration of $500 \mu \mathrm{g} \mathrm{mL}^{-1}$ without incubation with 3CL Pro (Raw).

Author Contributions: Conceptualization, J.P. and A.F.; methodology, C.G.-R., M.P. and A.F.; validation, C.G.-R., M.P. and A.F.; formal analysis, C.G.-R., A.R.-B. and J.P.; investigation, C.G.-R. and M.P.; resources, A.R.-B. and J.P.; data curation, C.G.-R.; writing-original draft preparation, C.G.-R., A.R.-B. and A.F.; writing - review and editing, A.R.-B. and J.P.; supervision, J.P. and A.F.; project administration, A.R.-B. and J.P.; funding acquisition, A.R.-B. and J.P. All authors have read and agreed to the published version of the manuscript.

Funding: This research received no external funding.

Data Availability Statement: Data are contained within the article or Supplementary Materials.

Conflicts of Interest: The authors declare no conflict of interest.

\section{References}

1. Salian, V.S.; Wright, J.A.; Vedell, P.T.; Nair, S.; Li, C.; Kandimalla, M.; Tang, X.; Porquera, E.M.C.; Kalari, K.R.; Kandimalla, K.K. COVID-19 transmission, current treatment, and future therapeutic strategies. Mol. Pharm. 2021, 18, 754-771. [CrossRef]

2. World Health Organization. Coronavirus Disease (COVID-19) Weekly Epidemiological Update and Weekly Operational Update. Coronavirus Disease (COVID-19). Available online: https://www.who.int/emergencies/diseases/novel-coronavirus-2019 / situation-reports (accessed on 8 April 2021).

3. Astuti, I.; Ysrafil. Severe Acute Respiratory Syndrome Coronavirus 2 (SARS-CoV-2): An overview of viral structure and host response. Diabetes Metab. Syndr. Clin. Res. Rev. 2020, 14, 407-412. [CrossRef] [PubMed]

4. Islam, M.R.; Hoque, M.N.; Rahman, M.S.; Ul Alam, A.S.M.R.; Akther, M.; Puspo, J.A.; Akter, S.; Sultana, M.; Crandall, K.A.; Hossain, M.A. Genome-wide analysis of SARS-CoV-2 virus strains circulating worldwide implicates heterogeneity. Sci. Rep. 2020, 10, 14004. [CrossRef]

5. Laamarti, M.; Alouane, T.; Kartti, S.; Chemao-Elfihri, M.W.; Hakmi, M.; Essabbar, A.; Laamarti, M.; Hlali, H.; Bendani, H.; Boumajdi, N.; et al. Large scale genomic analysis of 3067 SARS-CoV-2 genomes reveals a clonal geodistribution and a rich genetic variations of hotspots mutations. PLoS ONE 2020, 15, e0240345. [CrossRef] [PubMed]

6. Wang, R.; Chen, J.; Gao, K.; Hozumi, Y.; Yin, C.; Wei, G.-W. Analysis of SARS-CoV-2 mutations in the United States suggests presence of four substrains and novel variants. Commun. Biol. 2021, 4, 228. [CrossRef]

7. Forni, G.; Mantovani, A.; On Behalf of the COVID-19 Commission of Accademia Nazionale dei Lincei, Rome. COVID-19 vaccines: Where we stand and challenges ahead. Cell Death Differ. 2021, 28, 626-639. [CrossRef] [PubMed] 
8. European Centre for Disease Prevention and Control. SARS-CoV-2-Increased Circulation of Variants of Concern and Vaccine Rollout in the EU/EEA-14th Update; ECDC: Stockholm, Sweden, 2021; pp. 1-29.

9. Centers for Disease Control and Prevention. Interim Clinical Considerations for Use of COVID-19 Vaccines Currently Authorized in the United States. Available online: https:/ /www.cdc.gov/vaccines/covid-19/info-by-product/clinical-considerations.html (accessed on 8 March 2021).

10. World Health Organization. The Moderna COVID-19 (mRNA-1273) Vaccine: What You Need to Know. Available online: https:// www.who.int/news-room/feature-stories / detail/the-moderna-covid-19-mrna-1273-vaccine-what-you-need-to-know (accessed on 8 March 2021).

11. World Health Organization. COVID-19 Clinical Management. Living Guidance 25 January 2021; No. WHO/2019-nCoV/clinical/2021.1; WHO: Geneva, Switzerland, 2021.

12. Zhang, L.; Lin, D.; Sun, X.; Curth, U.; Drosten, C.; Sauerhering, L.; Becker, S.; Rox, K.; Hilgenfeld, R. Crystal structure of SARS-CoV-2 main protease provides a basis for design of improved a-ketoamide inhibitors. Science 2020, 368, 409-412. [CrossRef] [PubMed]

13. Li, T.; Liu, D.; Yang, Y.; Guo, J.; Feng, Y.; Zhang, X.; Cheng, S.; Feng, J. Phylogenetic supertree reveals detailed evolution of SARS-CoV-2. Sci. Rep. 2020, 10, 22366. [CrossRef]

14. Blanchard, J.E.; Elowe, N.H.; Huitema, C.; Fortin, P.D.; Cechetto, J.D.; Eltis, L.D.; Brown, E.D. High-throughput screening identifies inhibitors of the SARS Coronavirus Main Proteinase. Chem. Biol. 2004, 11, 1445-1453. [CrossRef]

15. Chen, C.N.; Lin, C.P.C.; Huang, K.K.; Chen, W.C.; Hsieh, H.P.; Liang, P.H.; Hsu, J.T.A. Inhibition of SARS-CoV 3C-like protease activity by theaflavin-3,3'- digallate (TF3). Evid. Based Complement. Altern. Med. 2005, 2, 209-215. [CrossRef]

16. Lin, C.-W.; Tsai, F.-J.; Tsai, C.-H.; Lai, C.-C.; Wan, L.; Ho, T.-Y.; Hsieh, C.; Chao, P.L. Anti-SARS coronavirus 3C-like protease effects of Isatis indigotica root and plant-derived phenolic compounds. Antivir. Res. 2005, 68, 36-42. [CrossRef]

17. Xian, Y.; Zhang, J.; Bian, Z.; Zhou, H.; Zhang, Z.; Lin, Z.; Xu, H. Bioactive natural compounds against human coronaviruses: A review and perspective. Acta Pharm. Sin. B 2020, 10, 1163-1174. [CrossRef] [PubMed]

18. Da Silva Antonio, A.; Wiedemann, L.S.M.; Veiga-Junior, V.F. Natural products' role against COVID-19. RSC Adv. 2020, 10, 23379-23393. [CrossRef]

19. Vougogiannopoulou, K.; Corona, A.; Tramontano, E.; Alexis, M.N.; Skaltsounis, A.-L. Natural and nature-derived products targeting human coronaviruses. Molecules 2021, 26, 448. [CrossRef] [PubMed]

20. Romeo, I.; Mesiti, F.; Lupia, A.; Alcaro, S. Current updates on naturally occurring compounds recognizing SARS-CoV-2 druggable targets. Molecules 2021, 26, 632. [CrossRef] [PubMed]

21. El-Missiry, M.A.; Fekri, A.; Kesar, L.A.; Othman, A.I. Polyphenols are potential nutritional adjuvants for targeting COVID-19. Phyther. Res. 2020, 35, 2879-2889. [CrossRef]

22. Zhou, J.; Huang, J. Current Findings Regarding Natural Components with Potential Anti-2019-nCoV Activity. Front. Cell Dev. Biol. 2020, 8, 589. [CrossRef] [PubMed]

23. Martins, N.; Barros, L.; Ferreira, I.C. In vivo antioxidant activity of phenolic compounds: Facts and gaps. Trends Food Sci. Technol. 2016, 48, 1-12. [CrossRef]

24. Zhou, Y.; Zheng, J.; Li, Y.; Xu, D.P.; Li, S.; Chen, Y.M.; Li, H.B. Natural polyphenols for prevention and treatment of cancer. Nutrients 2016, 8, 515. [CrossRef]

25. Lin, D.; Xiao, M.; Zhao, J.; Li, Z.; Xing, B.; Li, X.; Kong, M.; Li, L.; Zhang, Q.; Liu, Y.; et al. An overview of plant phenolic compounds and their importance in human nutrition and management of type 2 diabetes. Molecules 2016, 21, 1374. [CrossRef]

26. Godos, J.; Caraci, F.; Castellano, S.; Currenti, W.; Galvano, F.; Ferri, R.; Grosso, G. Association between dietary flavonoids intake and cognitive function in an Italian cohort. Biomolecules 2020, 10, 1300. [CrossRef]

27. Fahey, J.W.; Zhang, Y.; Talalay, P. Broccoli sprouts: An exceptionally rich source of inducers of enzymes that protect against chemical carcinogens. Proc. Natl. Acad. Sci. USA 1997, 94, 10367-10372. [CrossRef] [PubMed]

28. Jiang, X.; Liu, Y.; Ma, L.; Ji, R.; Qu, Y.; Xin, Y.; Lv, G. Chemopreventive activity of sulforaphane. Drug Des. Dev. Ther. 2018, 12, 2905-2913. [CrossRef] [PubMed]

29. López-Chillón, M.T.; Carazo-Díaz, C.; Prieto-Merino, D.; Zafrilla, P.; Moreno, D.A.; Villaño, D. Effects of long-term consumption of broccoli sprouts on inflammatory markers in overweight subjects. Clin. Nutr. 2019, 38, 745-752. [CrossRef] [PubMed]

30. Schepici, G.; Bramanti, P.; Mazzon, E. Efficacy of sulforaphane in neurodegenerative diseases. Int. J. Mol. Sci. 2020, 21 , 8637. [CrossRef]

31. Lin, C.; Kim, J.; Du, W.; Wei, C. Bactericidal Activity of Isothiocyanate against Pathogens on Fresh Produce. J. Food Prot. 2000, 63, 25-30. [CrossRef]

32. Kaiser, S.J.; Mutters, N.T.; Blessing, B.; Günther, F. Natural isothiocyanates express antimicrobial activity against developing and mature biofilms of Pseudomonas aeruginosa. Fitoterapia 2017, 119, 57-63. [CrossRef]

33. Liu, Y.; Huang, V.; Chao, T.-C.; Hsiao, C.-D.; Lin, A.; Chang, M.-F.; Chow, L.-P. Screening of drugs by FRET analysis identifies inhibitors of SARS-CoV 3CL protease. Biochem. Biophys. Res. Commun. 2005, 333, 194-199. [CrossRef]

34. Kuo, C.-J.; Chi, Y.-H.; Hsu, J.T.-A.; Liang, P.-H. Characterization of SARS main protease and inhibitor assay using a fluorogenic substrate. Biochem. Biophys. Res. Commun. 2004, 318, 862-867. [CrossRef]

35. Park, J.; Yuk, H.J.; Ryu, H.W.; Lim, S.H.; Kim, K.S.; Park, K.H.; Ryu, Y.B.; Lee, W.S. Evaluation of polyphenols from Broussonetia papyrifera as coronavirus protease inhibitors. J. Enzyme Inhib. Med. Chem. 2017, 32, 504-512. [CrossRef] 
36. Guijarro-Real, C.; Adalid-Martínez, A.M.; Aguirre, K.; Prohens, J.; Rodríguez-Burruezo, A.; Fita, A. Growing conditions affect the phytochemical composition of edible wall rocket (Diplotaxis erucoides). Agronomy 2019, 9, 858. [CrossRef]

37. Guijarro-Real, C.; Prohens, J.; Rodríguez-Burruezo, A.; Fita, A. Consumers acceptance and volatile profile of wall rocket (Diplotaxis erucoides). Food Res. Int. 2020, 132, 109008. [CrossRef] [PubMed]

38. Erlund, I. Review of the flavonoids quercetin, hesperetin, and naringenin. Dietary sources, bioactivities, bioavailability, and epidemiology. Nutr. Res. 2004, 24, 851-874. [CrossRef]

39. Manthey, J.A.; Grohmann, K. Concentrations of hesperidin and other orange peel flavonoids in citrus processing byproducts. J. Agric. Food Chem. 1996, 44, 811-814. [CrossRef]

40. Li, Y.; Kandhare, A.D.; Mukherjee, A.A.; Bodhankar, S.L. Acute and sub-chronic oral toxicity studies of hesperidin isolated from orange peel extract in Sprague Dawley rats. Regul. Toxicol. Pharmacol. 2019, 105, 77-85. [CrossRef]

41. Garcia-Castello, E.M.; Rodriguez-Lopez, A.D.; Mayor, L.; Ballesteros, R.; Conidi, C.; Cassano, A. Optimization of conventional and ultrasound assisted extraction of flavonoids from grapefruit (Citrus paradisi L.) solid wastes. LWT Food Sci. Technol. 2015, 64, 1114-1122. [CrossRef]

42. Zhang, M.; Duan, C.; Zang, Y.; Huang, Z.; Liu, G. The flavonoid composition of flavedo and juice from the pummelo cultivar (Citrus grandis (L.) Osbeck) and the grapefruit cultivar (Citrus paradisi) from China. Food Chem. 2011, 129, 1530-1536. [CrossRef]

43. Xi, W.; Lu, J.; Qun, J.; Jiao, B. Characterization of phenolic profile and antioxidant capacity of different fruit part from lemon (Citrus limon Burm.) cultivars. J. Food Sci. Technol. 2017, 54, 1108-1118. [CrossRef] [PubMed]

44. Gómez-Mejía, E.; Rosales-Conrado, N.; León-González, M.E.; Madrid, Y. Citrus peels waste as a source of value-added compounds: Extraction and quantification of bioactive polyphenols. Food Chem. 2019, 295, 289-299. [CrossRef]

45. De la Rosa, J.D.P.; Ruiz-Palomino, P.; Arriola-Guevara, E.; García-Fajardo, J.; Sandoval, G.; Guatemala-Morales, G.M. A green process for the extraction and purification of hesperidin from mexican lime peel (Citrus aurantifolia Swingle) that is extendible to the citrus genus. Processes 2018, 6, 266. [CrossRef]

46. Nogata, Y.; Sakamoto, K.; Shiratsuchi, H.; Ishii, T.; Yano, M.; Ohta, H. Flavonoid composition of fruit tissues of citrus species. Biosci. Biotechnol. Biochem. 2006, 70, 178-192. [CrossRef] [PubMed]

47. Guijarro-Real, C.; Prohens, J.; Rodriguez-Burruezo, A.; Adalid-Martínez, A.M.; López-Gresa, M.P.; Fita, A. Wild edible fool's watercress, a potential crop with high nutraceutical properties. PeerJ 2019, 7, e6296. [CrossRef]

48. Crozier, A.; Lean, M.E.J.; McDonald, M.S.; Black, C. Quantitative Analysis of the Flavonoid Content of Commercial Tomatoes, Onions, Lettuce, and Celery. J. Agric. Food Chem. 1997, 45, 590-595. [CrossRef]

49. Justesen, U.; Knuthsen, P.; Leth, T. Quantitative analysis of flavonols, flavones, and flavanones in fruits, vegetables and beverages by high performance liquid chromatography with photo-diode array and mass spectrometric detection. J. Chromatogr. A 1998, 799, 101-110. [CrossRef]

50. Hossain, M.B.; Rai, D.K.; Brunton, N.P.; Martin-Diana, A.B.; Barry-Ryan, A.C. Characterization of phenolic composition in lamiaceae spices by LC-ESI-MS/MS. J. Agric. Food Chem. 2010, 58, 10576-10581. [CrossRef] [PubMed]

51. Martins, N.; Barros, L.; Santos-Buelga, C.; Henriques, M.; Silva, S.; Ferreira, I.C. Decoction, infusion and hydroalcoholic extract of Origanum vulgare L.: Different performances regarding bioactivity and phenolic compounds. Food Chem. 2014, 158, 73-80. [CrossRef]

52. Justesen, U.; Knuthsen, P. Composition of flavonoids in fresh herbs and calculation of flavonoid intake by use of herbs in traditional Danish dishes. Food Chem. 2001, 73, 245-250. [CrossRef]

53. Srivastava, J.K.; Gupta, S. Extraction, Characterization, Stability and Biological Activity of Flavonoids Isolated from Chamomile Flowers. Mol. Cell. Pharmacol. 2009, 1, 138. [CrossRef]

54. Svehlıkova, V.; Bennett, R.N.; Mellon, F.A.; Needs, P.W.; Piacente, S.; Kroon, P.A.; Bao, Y. Isolation, identification and stability of acylated derivatives of apigenin 7-O-glucoside from chamomile (Chamomilla recutita [L.] Rauschert). Phytochemistry 2004, 65, 2323-2332. [CrossRef]

55. Yang, Q.Q.; Cheng, L.Z.; Zhang, T.; Yaron, S.; Jiang, H.X.; Sui, Z.Q.; Corke, H. Phenolic profiles, antioxidant, and antiproliferative activities of turmeric (Curcuma longa). Ind. Crops Prod. 2020, 152, 112561. [CrossRef]

56. Sepahpour, S.; Selamat, J.; Manap, M.Y.A.; Khatib, A.; Razis, A.F.A. Comparative analysis of chemical composition, antioxidant activity and quantitative characterization of some phenolic compounds in selected herbs and spices in different solvent extraction systems. Molecules 2018, 23, 402. [CrossRef]

57. Al Shahawany, A.W.; Al Hattab, Z.N.; Al Tahhan, S.F. Qualitative and Quantitative Analysis of Sinigrin in Different Parts In Vitro and In Vivo of Brassica nigra Plants. Biomed. Biotechnol. 2016, 4, 19-24. [CrossRef]

58. Rangkadilok, N.; Nicolas, M.E.; Bennett, R.N.; Premier, R.R.; Eagling, D.R.; Taylor, P. Developmental changes of sinigrin and glucoraphanin in three Brassica species (Brassica nigra, Brassica juncea and Brassica oleracea var. italica). Sci. Hortic. 2002, 96, 11-26. [CrossRef]

59. Agneta, R.; Lelario, F.; De Maria, S.; Möllers, C.; Bufo, S.A.; Rivelli, A.R. Glucosinolate profile and distribution among plant tissues and phenological stages of field-grown horseradish. Phytochemistry 2014, 106, 178-187. [CrossRef]

60. Popović, M.; Maravić, A.; Čulić, V.Č.; Đulović, A.; Burčul, F.; Blažević, I. Biological effects of glucosinolate degradation products from horseradish: A horse that wins the race. Biomolecules 2020, 10, 343. [CrossRef]

61. Di Gioia, F.; Avato, P.; Serio, F.; Argentieri, M.P. Glucosinolate profile of Eruca sativa, Diplotaxis tenuifolia and Diplotaxis erucoides grown in soil and soilless systems. J. Food Compos. Anal. 2018, 69, 197-204. [CrossRef] 
62. Borges-Argáez, R.; Chan-Balan, R.; Cetina-Montejo, L.; Ayora-Talavera, G.; Sansores-Peraza, P.; Gómez-Carballo, J.; CáceresFarfán, M. In vitro evaluation of anthraquinones from Aloe vera (Aloe barbadensis Miller) roots and several derivatives against strains of influenza virus. Ind. Crops Prod. 2019, 132, 468-475. [CrossRef]

63. Bae, H.; Jayaprakasha, G.K.; Jifon, J.; Patil, B.S. Extraction efficiency and validation of an HPLC method for flavonoid analysis in peppers. Food Chem. 2012, 130, 751-758. [CrossRef]

64. Selmi, S.; Rtibi, K.; Grami, D.; Sebai, H.; Marzouki, L. Protective effects of orange (Citrus sinensis L.) peel aqueous extract and hesperidin on oxidative stress and peptic ulcer induced by alcohol in rat. Lipids Health Dis. 2017, 16, 152. [CrossRef] [PubMed]

65. Doheny-Adams, T.; Redeker, K.; Kittipol, V.; Bancroft, I.; Hartley, S.E. Development of an efficient glucosinolate extraction method. Plant Methods 2017, 13, 1-14. [CrossRef] [PubMed]

66. Tsao, R.; Yu, Q.; Potter, J.; Chiba, M. Direct and simultaneous analysis of sinigrin and allyl isothiocyanate in mustard samples by high-performance liquid chromatography. J. Agric. Food Chem. 2002, 50, 4749-4753. [CrossRef]

67. Fehr, A.R.; Perlman, S. Coronaviruses: An overview of their replication and pathogenesis. Methods Mol. Biol. 2015, 1282, 1-23. [CrossRef] [PubMed]

68. World Health Organization. Coronavirus Disease 2019 (COVID-19): Situation Report-94; WHO: Geneva, Switzerland, 2020.

69. Hilgenfeld, R. From SARS to MERS: Crystallographic studies on coronaviral proteases enable antiviral drug design. FEBS J. 2014, 281, 4085-4096. [CrossRef]

70. Gurung, A.B.; Ali, M.A.; Lee, J.; Farah, M.A.; Al-Anazi, K.M. Unravelling lead antiviral phytochemicals for the inhibition of SARS-CoV-2 M pro enzyme through in silico approach. Life Sci. 2020, 255, 117831. [CrossRef] [PubMed]

71. Chen, Y.W.; Yiu, C.P.B.; Wong, K.Y. Prediction of the SARS-CoV-2 (2019-nCoV) 3C-like protease (3CL $\left.{ }^{\text {pro }}\right)$ structure: Virtual $^{2}$ screening reveals velpatasvir, ledipasvir, and other drug repurposing candidates. F1000Research 2020, 9, 129. [CrossRef]

72. Ryu, Y.B.; Jeong, H.J.; Kim, J.H.; Kim, Y.M.; Park, J.Y.; Kim, D.; Naguyen, T.T.H.; Park, S.J.; Chang, J.S.; Park, K.H.; et al. Biflavonoids from Torreya nucifera displaying SARS-CoV 3CL ${ }^{\text {ro }}$ inhibition. Bioorg. Med. Chem. 2010, 18, 7940-7947. [CrossRef]

73. Cheng, L.; Zheng, W.; Li, M.; Huang, J.; Bao, S.; Xu, Q.; Ma, Z. Citrus fruits are rich in flavonoids for immunoregulation and potential targeting ACE2. Preprints 2020. [CrossRef]

74. Utomo, R.Y.; Ikawati, M.; Meiyanto, E. Revealing the Potency of Citrus and Galangal Constituents to Halt SARS-CoV-2 Infection. Preprints 2020. [CrossRef]

75. Adem, S.; Eyupoglu, V.; Sarfraz, I.; Rasul, A.; Ali, M. Identification of potent COVID-19 main protease (Mpro) inhibitors from natural polyphenols: An in silico strategy unveils a hope against CORONA. Preprints 2020. [CrossRef]

76. Pendyala, B.; Patrasa, A. In silico screening of food bioactive compounds to predict potential inhibitors of COVID-19 Main protease (MPro) and RNA-dependent RNA polymerase (RdRp). ChemRxiv 2020. [CrossRef]

77. Khaerunnisa, S.; Kurniawan, H.; Awaluddin, R.; Suhartati, S.; Soetjipto, S. Potential inhibitor of COVID-19 Main Protease (Mpro) from several medicinal plant compounds by molecular docking study. Preprints 2020. [CrossRef]

78. Tayyem, R.F.; Heath, D.D.; Al-Delaimy, W.K.; Rock, C.L. Curcumin content of turmeric and curry powders. Nutr. Cancer 2006, 55, 126-131. [CrossRef]

79. Chao, I.-C.; Wang, C.-M.; Li, S.-P.; Lin, L.-G.; Ye, W.-C.; Zhang, Q.-W. Simultaneous quantification of three curcuminoids and three volatile components of Curcuma longa using pressurized liquid extraction and high-performance liquid chromatography. Molecules 2018, 23, 1568. [CrossRef]

80. Miean, K.H.; Mohamed, S. Flavonoid (myricetin, quercetin, kaempferol, luteolin, and apigenin) content of edible tropical plants. J. Agric. Food Chem. 2001, 49, 3106-3112. [CrossRef]

81. Abian, O.; Ortega-Alarcon, D.; Jimenez-Alesanco, A.; Ceballos-Laita, L.; Vega, S.; Reyburn, H.T.; Rizzuti, B.; Velazquez-Campoy, A. Structural stability of SARS-CoV-2 3CLpro and identification of quercetin as an inhibitor by experimental screening. Int. J. Biol. Macromol. 2020, 164, 1693-1703. [CrossRef]

82. Olaimat, A.N.; Al-Holy, M.A.; Abu Ghoush, M.; Al-Nabulsi, A.A.; Holley, R.A. Control of Salmonella enterica and Listeria monocytogenes in hummus using allyl isothiocyanate. Int. J. Food Microbiol. 2018, 278, 73-80. [CrossRef]

83. Borges, A.; Abreu, A.C.; Ferreira, C.; Saavedra, M.J.; Simões, L.C.; Simões, M. Antibacterial activity and mode of action of selected glucosinolate hydrolysis products against bacterial pathogens. J. Food Sci. Technol. 2015, 52, 4737-4748. [CrossRef] [PubMed]

84. Xiao, D.; Srivastava, S.K.; Lew, K.L.; Zeng, Y.; Hershberger, P.; Johnson, C.S.; Trump, D.L.; Singh, S.V. Allyl isothiocyanate, a constituent of cruciferous vegetables, inhibits proliferation of human prostate cancer cells by causing G2/M arrest and inducing apoptosis. Carcinogenesis 2003, 24, 891-897. [CrossRef] [PubMed]

85. Srivastava, S.K.; Xiao, D.; Lew, K.L.; Hershberger, P.; Kokkinakis, D.M.; Johnson, C.S.; Trump, D.L.; Singh, S.V. Allyl isothiocyanate, a constituent of cruciferous vegetables, inhibits growth of PC-3 human prostate cancer xenograft in vivo. Carcinogenesis 2003, 24, 1665-1670. [CrossRef] [PubMed]

86. Sávio, A.L.V.; da Silva, G.N.; Salvadori, D.M.F. Inhibition of bladder cancer cell proliferation by allyl isothiocyanate (mustard essential oil). Mutat. Res. 2015, 771, 29-35. [CrossRef] [PubMed]

87. Citi, V.; Martelli, A.; Brancaleone, V.; Brogi, S.; Gojon, G.; Montanaro, R.; Morales, G.; Testai, L.; Calderone, V. Anti-inflammatory and antiviral roles of hydrogen sulfide: Rationale for considering H2S donors in COVID-19 therapy. Br. J. Pharmacol. 2020, 177, 4931-4941. [CrossRef] [PubMed] 